\title{
Uji daya hambat ekstrak daun awar-awar (ficus septica burm.f) terhadap pertumbuhan bakteri staphylococcus aureus dan eschericia coli
}

\author{
${ }^{1}$ Ismiranti D. A. Tuna \\ ${ }^{2}$ Pemsi M. Wowor \\ ${ }^{2}$ Henoch Awaloei
}

\author{
${ }^{1}$ Kandidat Skripsi Fakultas Kedokteran Universitas Sam Ratulangi Manado \\ ${ }^{2}$ Bagian Farmakologi dan Terapi Fakultas Kedokteran Universitas Sam Ratulangi Manado \\ Email: ismiranti14@gmail.com
}

\begin{abstract}
Awar-awar (Ficus septica Burm.F) is one of the plants that used by comunities. Based from the empiric data, this plant is believed have efficacy as a drug and could treat diseases. Staphylococcus aureus dan Eschericia coli are the most frequent causal organism in human bacterial infection. This study aimed to determine whether there is inhibition of leaf extract awar-awar against Staphylococcus aureus and Eschericia coli. This was a laboratory experimental with Kirby-Bauer pitting modification at Phytochemistry and Microbiology Laboratory of Sam Ratulangi University Faculty of Mathematics and natural Science. Awar-awar leaf extract was obtained from maceration process with $96 \%$ ethanol. Consentration of thick extract that was used were $100 \mathrm{mg} / \mathrm{ml}, 50 \mathrm{mg} / \mathrm{ml}, 25 \mathrm{mg} / \mathrm{ml}, 12,5$ $\mathrm{mg} / \mathrm{ml}$. ciprofloxacin was used as positive control,and aquades was used as negative control. The result showed that the average of inhibition diemeters by awar-awar leaves were 100 $\mathrm{mg} / \mathrm{ml}, 50 \mathrm{mg} / \mathrm{ml}, 25 \mathrm{mg} / \mathrm{ml}, 12,5 \mathrm{mg} / \mathrm{ml}$ respectively are $27,5 \mathrm{~mm}, 24,3 \mathrm{~mm}, 22,3 \mathrm{~mm}$, 21,8 in Staphylococcus aureus, whereas in Eschericia coli were 24,8 mm, $21 \mathrm{~mm}, 18,3 \mathrm{~mm}$, $17 \mathrm{~mm}$. Conclusion: Awar-awar leaf extract has a potential inhibion effect on the growth of Staphylococcus aureus and Eschericia coli.
\end{abstract}

Keywords: awar-awar leaves extract, staphylococcus aureus, eschericia coli, inhibition test.

\begin{abstract}
Abstrak: Tanaman awar-awar merupakan salah satu tanaman yang digunakan masyarakat untuk pengobatan. Berdasarkan data empiris, tanaman ini dipercaya memiliki khasiat sebagai obat dan bisa mengobati penyakit. Bakteri Staphylococcus aureus dan Eschericia coli merupakan penyebab infeksi utama pada manusia. Penelitian ini bertujuan untuk mengetahui ada tidaknya daya hambat ekstrak daun awar-awar terhadap bakteri Staphylococcus aureus dan Eschericia coli. Jenis penelitian ini ialah eksperimental laboratorium dengan modifikasi Kirby-Bauer sumuran di Laboratorium Fitokimia dan Mikrobiologi Fakultas MIPA Universitas sam Ratulangi. Ekstrak daun awar-awar diperoleh dari proses maserasi dengan etanol 96\%. Konsentrasi ekstrak kental yang digunakan dalam penelitian ini ialah 100 $\mathrm{mg} / \mathrm{ml}, 50 \mathrm{mg} / \mathrm{ml}, 25 \mathrm{mg} / \mathrm{ml}, 12,5 \mathrm{mg} / \mathrm{ml}$. Siprofloksasin sebagai kontrol positif, dan akuades sebagai kontrol negatif. Hasil penelitian mendapatkan rata-rata diameter zona hambat ekstrak daun awar-awar konsentrasi $100 \mathrm{mg} / \mathrm{ml}, 50 \mathrm{mg} / \mathrm{ml}, 25 \mathrm{mg} / \mathrm{ml}, 12,5 \mathrm{mg} / \mathrm{ml}$ berturut-turut ialah 27,5 mm, 24,3 mm, 22,3 mm, 21,8 mm pada bakteri Staphylococcus aureus, sedangkan pada bakteri Eschericia coli ialah 24,8 mm, $21 \mathrm{~mm}, 18,3 \mathrm{~mm}, 17 \mathrm{~mm}$. Simpulan: Ekstrak daun awar-awar berpotensi memiliki daya hambat terhadap pertumbuhan bakteri Staphylococcus aureus dan Eschericia coli.
\end{abstract}

Kata kunci: ekstrak daun awar-awar, staphylococcus aureus, eschericia coli, uji daya hambat. 
Tuna, Wowor, Awaloei: uji daya hambat...

Penggunaan tanaman yang diyakini berkhasiat sebagai obat telah berlangsung di berbagai negara sejak ribuan tahun yang lalu dan diwariskan secara turuntemurun. ${ }^{1,2}$ Di Papua Nugini, tanaman awarawar (Ficus septica Burm.F) digunakan sebagai obat untuk meredakan batuk, sakit kepala, menurunkan demam, mengobati sakit perut, mencegah diare, mengobati luka dan sebagai obat untuk infeksi jamur. ${ }^{3}$

Ekstrak daun awar-awar mengandung senyawa terpenoid, alkaloid, flavonoid, dan fenol yang berpotensi menghambat pertumbuhan jamur.

Staphylococcus aureus dan Eschericia coli merupakan organisme penyebab infeksi yang paling sering pada manusia. ${ }^{5}$

Berasarkan uraian diatas, penulis merasa tertarik untuk melakukan penelitian untuk mengetahui daya hambat ekstrak daun awar-awar terhadap pertumbuhan bakteri Staphylococcus aureus dan Eschericia coli

\section{METODE PENELITIAN}

Penelitian ini merupakan penelitian eksperimental laboratorium, dilakukan di Laboratorium Penelitian dan Mikrobiologi Program studi Farmasi FMIPA Universitas Sam Ratulangi.

Tahapan penelitian ialah sterilisasi alat, pengambilan sampel, pembuatan ekstrak daun awar-awar dengan cara maserasi, pengenceran ekstrak daun awar-awar, pembuatan media pembenihan bakteri Muller-Hinton Agar (MHA), pembuatan suspensi bakteri dan pengujian bakteri. Akuades sebagai kontrol negatif sedangkan siprofloksasin digunakan sebagai kontrol positif. Ekstrak daun awar-awardengan berbagai konsentrasi $\quad(1000 \mathrm{mg} / \mathrm{ml}$, $50 \mathrm{mg} / \mathrm{ml}, 25 \mathrm{mg} / \mathrm{ml}$, dan $12,5 \mathrm{mg} / \mathrm{ml})$, kontrol positif dan kontrol negatif diteteskan sebanyak $50 \mu 1$ pada sumur yang berbeda, kemudian cawan petri dimasukkan dalam inkubator pada suhu $37^{\circ} \mathrm{C}$ selama 18-24 jam. Pengamatan dilakukan pada jam ke-18 dan jam ke-24 jam inkubasi, diukur diameter zona hambat yang terbentuk dengan menggunakan mistar satuan milimeter.

Zona bening merupakan petunjuk kepekaan bakteri terhadap bahan antibakteri yang digunakan sebagai bahan uji dan dinyatakan dengan diameter zona hambat.

Diameter zona hambat dapat diukur dengan rumus :

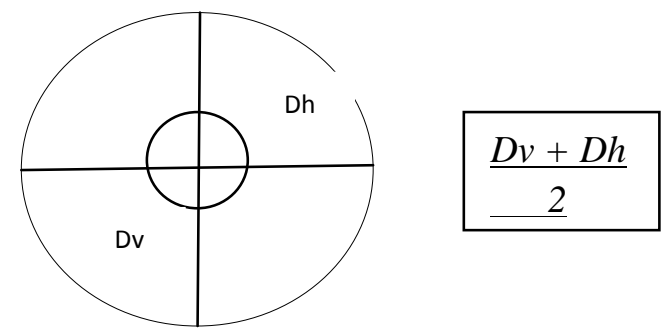

Dh : Diameter horizontal
Dv : Diameter vertikal

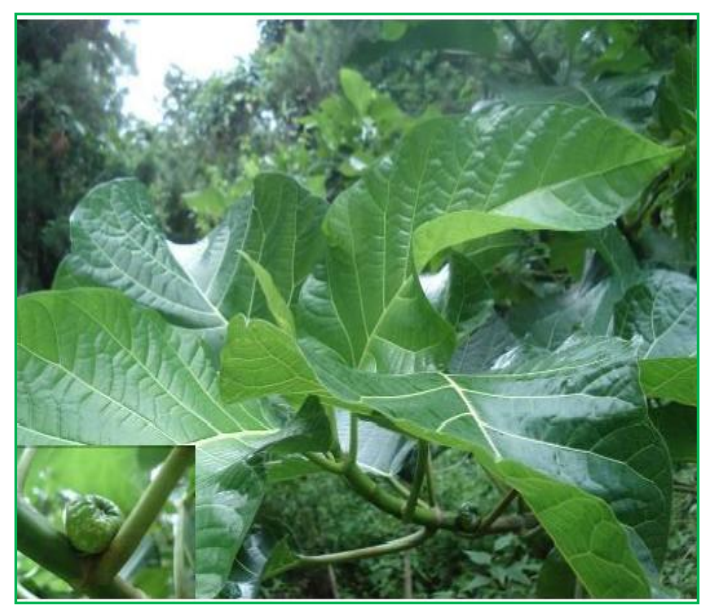

Gambar 1. Daun Ficus septica Burm.F

\section{HASIL PENELITIAN}

Hasil pengujian daya hambat ekstrak daun awar-awarterhadap pertumbuhan Staphylococcus aureus dan Escherichia coli pada pengamatan 18 jam dan 24 jam inkubasi dengan 3 kali pengulangan menunjukan hasil yang positif. Hal ini ditunjukkan dengan terbentuknya zona jernih disekitar sumuran kontrol positif dan kelompok perlakuan ekstrak daun awarawar. Sekitar sumuran kontrol negatif tidak terbentuk zona jernih. 
A. Pengamatan 1

Pengamatan 1 dilakukan pada waktu inkubasi 18 jam, yaitu pukul 12.30 WITA.

Tabel 1. Diameter zona hambat kontrol dan perlakuan pada S.aureus pada pengamatan 1

\begin{tabular}{lllllll}
\hline Cawan & & \multicolumn{5}{c}{ Staphylococcus aures } \\
Petri & $100 \mathrm{mg} / \mathrm{ml}$ & $50 \mathrm{mg} / \mathrm{ml}$ & $25 \mathrm{mg} / \mathrm{ml}$ & $12,5 \mathrm{mg}, \mathrm{ml}$ & $\mathrm{K}+$ & $\mathrm{K}-$ \\
\hline $\mathrm{A}$ & 25,5 & 22 & 21 & 20,5 & 29 & 0 \\
$\mathrm{~B}$ & 29 & 21 & 19,5 & 21 & 34,5 & 0 \\
C & 25 & 24 & 21,5 & 19,5 & 29,5 & 0 \\
Rata-rata & 26,3 & 24,3 & 20,6 & 20,3 & 31,1 & 0 \\
\hline
\end{tabular}

Tabel 2. Diameter zona hambat kontrol dan perlakuan pada E.colipada pengamatan 1

\begin{tabular}{lllllll}
\hline $\begin{array}{l}\text { Cawan } \\
\text { Petri }\end{array}$ & $100 \mathrm{mg} / \mathrm{ml}$ & $50 \mathrm{mg} / \mathrm{ml}$ & $25 \mathrm{mg} / \mathrm{ml}$ & $12,5 \mathrm{mg}, \mathrm{ml}$ & $\mathrm{K}+$ & $\mathrm{K}$ - \\
\hline $\mathrm{A}$ & 24,5 & 20 & 17 & 16,5 & 29,5 & 0 \\
$\mathrm{~B}$ & 22 & 16,5 & 15 & 12,5 & 22,5 & 0 \\
$\mathrm{C}$ & 21 & 19 & 23 & 15,5 & 26,3 & 0 \\
Rata-rata & 22,5 & 18,5 & 18,3 & 14,3 & 32,83 & 0 \\
\hline
\end{tabular}

Keterangan : $100 \mathrm{mg} / \mathrm{ml}$. konsentrasi $100 \mathrm{mg} / \mathrm{ml} ; 50 \mathrm{mg} / \mathrm{ml}$. konsentrasi $50 \mathrm{mg} / \mathrm{ml} ; 25 \mathrm{mg} / \mathrm{ml}$. konsentrasi $25 \mathrm{mg} / \mathrm{ml} ; 12,5 \mathrm{mg} / \mathrm{ml}$. konsentrasi 12,5mg/ml; K-. kontrol negatif; K+. kontrol positif.

B. Pengamatan 2

Pengamatan 2 dilakukan pada waktu inkubasi 24 jam, yaitu pukul 18.30 WITA.

Tabel 3. Diameter zona hambat kontrol dan perlakuan pada S.aureus pada pengamatan 2

\begin{tabular}{lllllll}
\hline Cawan & & \multicolumn{5}{c}{ Staphylococcus aures } \\
Petri & $100 \mathrm{mg} / \mathrm{ml}$ & $50 \mathrm{mg} / \mathrm{ml}$ & $25 \mathrm{mg} / \mathrm{ml}$ & $12,5 \mathrm{mg}, \mathrm{ml}$ & $\mathrm{K}+$ & $\mathrm{K}-$ \\
\hline A & 26,5 & 24,5 & 24 & 22,5 & 39 & 0 \\
B & 29,5 & 23,5 & 21 & 22 & 39,5 & 0 \\
C & 26,5 & 25 & 22 & 21 & 39,5 & 0 \\
Rata-rata & 27,5 & 24,3 & 22,3 & 21,8 & 38 & 0 \\
\hline
\end{tabular}

Tabel 4. Diameter zona hambat kontrol dan perlakuan pada E.colipada pengamatan 2

\begin{tabular}{lllllll}
\hline $\begin{array}{l}\text { Cawan } \\
\text { Petri }\end{array}$ & $100 \mathrm{mg} / \mathrm{ml}$ & $50 \mathrm{mg} / \mathrm{ml}$ & $25 \mathrm{mg} / \mathrm{ml}$ & $12,5 \mathrm{mg}, \mathrm{ml}$ & $\mathrm{K}+$ & $\mathrm{K}$ - \\
\hline $\mathrm{A}$ & 25 & 20,5 & 16 & 17,5 & 31,5 & 0 \\
$\mathrm{~B}$ & 23 & 21,5 & 17 & 15,5 & 31 & 0 \\
$\mathrm{C}$ & 26,5 & 21 & 22 & 18 & 29,5 & 0 \\
Rata-rata & 24,8 & 21 & 18,3 & 17 & 34 & 0 \\
\hline
\end{tabular}

Keterangan : $100 \mathrm{mg} / \mathrm{ml}$. konsentrasi $100 \mathrm{mg} / \mathrm{ml} ; 50 \mathrm{mg} / \mathrm{ml}$. konsentrasi $50 \mathrm{mg} / \mathrm{ml} ; 25 \mathrm{mg} / \mathrm{ml}$. konsentrasi $25 \mathrm{mg} / \mathrm{ml} ; 12,5 \mathrm{mg} / \mathrm{ml}$. konsentrasi $12,5 \mathrm{mg} / \mathrm{ml}$; K-. kontrol negatif; K+. kontrol positif.

\section{BAHASAN}

Ekstrak daun awar-awar dalam berbagai konsentrasi menunjukkan variasi ukuran diameter daya hambat terhadap pertumbuhan kedua bakteri. Berdasarkan hasil pengamatan yang dilakukan pada kelompok perlakuan, terjadi peningkatan

rata-rata diameter zona hambat seiring dengan meningkatnya konsentrasi ekstrak daun awar-awar $(100 \mathrm{mg} / \mathrm{ml}>50 \mathrm{mg} / \mathrm{ml}>$ $25 \mathrm{mg} / \mathrm{ml}>12,5 \mathrm{mg} / \mathrm{ml}$ ).

Hasil pengukuran menunjukan diameter rata-rata zona hambat yang 
terbentuk pada media tanam bakteri S.aureus lebih besar dari pada bakteri E.coli. Hal ini didukung oleh beberapa penelitian sebelumnya yang menunjukan bakteri Gram positif lebih rentan terhadap zat aktif dalam ekstrak dibandingkan bakteri Gram negatif. ${ }^{6}$ Hal ini berkaitan dengan perbedaan sifat dan dinding sel pada kedua bakteri Bakteri Gram positif mempunyai taut lapisan peptidoglikan yang memungkinkan bakteri mudah menyerap ekstrak. Sebaliknya, bakteri Gram negatif mempunyai membran luar yang terdiri dari lipopolisakarida yang bisa menghalangi penetrasi ekstrak ke dalam sel mikroba. ${ }^{7}$

Zona hambat yang terbentuk pada kontrol positif (siprofloksasin) terlihat bening dan lebih besar dibanding kelompok perlakuan pada tiap pengamatan yang dilakukan. Siprofloksasin dipilih sebagai kontrol positif karena merupakan antibiotik spektrum luas yang merupakan salah satu obat pilihan untuk infeksi bakteri E.coli dan sensitif terhadap bakteri S.aureus yang resisten terhadap metisilin. ${ }^{8}$

Pada penelitian ini, tidak ditemukan adanya zona hambat pada kontrol negatif yaitu aquades, yang merupakan larutan pengencer kontrol positif dan ekstrak daun awar-awar. Dari hasil penelitian ini dapat disimpulkan bahwa ekstrak daun awarawar memiliki daya hambat terhadap pertumbuhan bakteri S.aureus dan E.coli, tetapi zona hambatnya lebih kecil dibandingkan antibiotik siprofloksasin.

\section{SIMPULAN}

Ekstrak daun awar-awar berpotensi memiliki daya hambat terhadap pertumbuhan bakteri S.aureus dan E.coli. Daya hambat ekstrak daun awar-awar lebih besar pada S.aureus daripada E.coli.

\section{DAFTAR PUSTAKA}

1. Kementerian Kesehatan RI. Peraturan menteri kesehatan Republik Indonesia nomor 88 tahun 2013 tentang rencana induk pengembangan bahan baku obat. Jakarta: Berita Negara Republik Indonesia; 2013 h.12

2. Widjaja EA, Rahayuningsih Y, Rahajoe JS, Ubaidillah $\mathbf{R}$, Maryanto I, Walujo EB. Semiadi G. Kekinian keanekaragaman hayati indonesia. Jakarta: LIPI Press ; 2014. h. 170-2.

3. World Health Organization, Regional Office for the Western Pacific in Manila, the Philippines. Medical Plants in Papua New Guinea. WHO Press ; 2009. h. 124-125.

4. Sudirga SK. Isolasi dan identifikasi senyawa aktif ekstrak daun awar-awar (Ficus septica Burm. F) dan uji evektivitasnya terhadap jamur Colletotrichum acutatum. Universitas Udayana.

5. Kayser FH, Bacteria as human pathogens. Dalam: Kayser FH, Bienz KA, Eckret $\mathrm{J}$, Zinkernagel RM. Color atlas of microbiology. Germany: Wemding; 2005. h.229-32.

6. Pierangeli GV, Rongelio NV, Josemaria MD, Windell LR. Antimicrobal activity, citotoxicity and phytochemical screening of Ficus septica Burm and Sterculia foetida L. leaf extracts. Journal of Medicinal Plants Research Vol. 4(1) 2010 January; 58-63.

7. Neidhardt FC. Bacterial structures. Dalam: Ryan KJ, Ray CG, penyunting. Sherris medical microbiology an introduction to infectious disease. Edisi 4. McGraw-hill; h.11-20.

8. Food and drug administrator organization. Cipro. USA: Departement of health and human service; 2004. 